PUBLIC HEALTH RESEARCH

\title{
Post-Flood Impact on the Quality of Life of Victims in East Coast Malaysia
}

\author{
Azmawati Mohammed Nawi, Sharifa Ezat Wan Puteh, Rozita Hod, Idayu Badilla Idris, Izzah Syazwani Ahmad \\ and Qistina Mohd Ghazali
}

Department of Community Health, University Kebangsaan Malaysia Medical Centre (UKMMC), Faculty of Medicine, Universiti Kebangsaan Malaysia, Cheras Kuala Lumpur, Malaysia.

*For reprint and all correspondence: Assoc. Prof. Dr Azmawati Mohammed Nawi, Department of Community Health, University Kebangsaan Malaysia Medical Centre (UKMMC), Faculty of Medicine, Universiti Kebangsaan Malaysia, Cheras Kuala Lumpur, Malaysia.

Email:azmawati@ppukm.ukm.edu.my

\section{ABSTRACT}

\begin{tabular}{ll}
\hline $\begin{array}{l}\text { Received } \\
\text { Accepted }\end{array}$ & $\begin{array}{l}\text { 28 September 2020 } \\
\text { 10 December 2020 }\end{array}$ \\
Introduction & $\begin{array}{l}\text { This study aimed to evaluate the quality of life among flood victims exposed } \\
\text { at three worst districts in Pahang, Malaysia } \\
\text { Methods }\end{array}$ \\
& $\begin{array}{l}\text { Semi-guided questionnaires were distributed randomly to a total of } 602 \text { flood } \\
\text { victims. Quality of life (QOL) was measured using WHO Quality of Life- } \\
\text { BREF (WHOQOL-BREF), which was assessed based on four domains, i.e. } \\
\text { physical activity, psychological, social relationships and environment. }\end{array}$ \\
& $\begin{array}{l}\text { Victims of the flood had a poorer quality of life in all the domains especially } \\
\text { physical (59.0\%) and psychological (53.3\%) domain. The impact of the flood }\end{array}$ \\
& $\begin{array}{l}\text { on QOL was higher among women, those who reside in the urban area, the } \\
\text { elderlies and persons with high education and income. }\end{array}$ \\
Fonclusions & $\begin{array}{l}\text { Flood event has reduced the QOL of victims. The impact of flood has been } \\
\text { found to be mitigated over the time and relief efforts. Interventions aimed to } \\
\text { reduce these concerns in acute post-flood areas are essential to minimize poor } \\
\text { QOL among the affected victims. }\end{array}$ \\
Feywords & Flood - WHOQOL-BREF - Malaysia - victim - QOL - urban.
\end{tabular}




\section{INTRODUCTION}

Floods occurs almost every year and leads to number of deaths especially in the low-income countries. ${ }^{1}$ Climate change is the main reason for the increased flood occurrence, ${ }^{2}$ and the impact would be high in the south and east $\mathrm{Asia}^{3}$ including Malaysia.

Flood occurrence has become a national issue in Malaysia as it possed threatened to the life and property as well as disrupts the social and economic activities. Flood has been listed as the major and the most severe threat among all the disasters in Malaysia., ${ }^{4,5}$ There are more than 85 water basins have been identified as prone to flood. The prevalence of floods occurrence seems to be higher in recent years. This phenomenon may be due to the anthropogenic activities that leads to natural disasters in which occurs not only in this country but all around the world. In 1886, severe flood with gale-force winds caused extensive damages in Kelantan. The flood in 1926, has affected most of the Peninsular Malaysia, resulting in the worst disaster to the health, property and crops. Subsequently in 1967, another severe flood event occurred in Kelantan, Terengganu and Perak which has caused 55 deaths. ${ }^{6}$

Following that, in 1971, many parts of the country especially Pahang were affected by a catastrophic flood. In October 2003, major flooding affected a large area in the northwestern part of the Peninsular Malaysia, including the states of Kedah, Penang and Northern Perak. ${ }^{7}$ In another event, the 2007 floods were considered worst in the recent history of Malaysia after more than 30 years since 1971. It has caused severe damage tothe northern region of Peninsular Malaysia particularly in Kota Tinggi, Johor. ${ }^{8}$ However, there was an unprecedented flooding occurred in the late December, 2014 in Malaysia which has resulted in severe damage throughout Kelantan, Terengganu, Pahang and Perak. ${ }^{9}$ In Pahang, although flood occur almost every year, Puteh et al. (2018) ${ }^{10}$ stated that the community was still not able to adapt to the flood events. The recognition of an area that contributes to the flood 2014 in Pahang was the main issues aimed to be addressed in this paper.

Floods has been widely acknowledged to increase the potential of vacate risk and impacts on human health. The health part includes factors such as the increase in the burden of disease, morbidity, mortality, social and economy. The flooding affects on health depends on a country's geographical and socio-economical status as well as the underlying weakness among the affected population. ${ }^{11}$ Many epidemiological studies have been carried out to investigate the health effects in such situation. It can be divided into short-term effects and long term effects. Short term effects occurs during the floods or in the first months of flooding. The effects were including death, drowning, injury, toxic exposure and infectious diseases, especially water-borne diseases such as typhoid, hepatitis, leptospirosis, cholera and food poisoning. Long-term effects were such as post-traumatic stress disorder (PTSD), ${ }^{12}$ non-communicable diseases, malnutrition, anxiety or depression. ${ }^{13}$

Tan et al. (2004) (14) believed that the quality of life (QOL) of an individual might be affected due to the flood event. QOL is a comprehensive index of health status. ${ }^{15}$ The World Health Organization (WHO) defines QOL as the individual's perception of their position in the life, in the context of the culture and value systems in which they live. In addition, perception about their goals, expectations, standards and concerns were also valued in assessing the QOL. ${ }^{16}$ The QOL has been used widely in social science as a measure of social development and living standard. In recent years, QOL has been used as a tool to access the impact of natural disasters such as earthquake, ${ }^{17}, 18$, ${ }^{19}$ flood $^{10,20}$ and wildfires. ${ }^{21}$ Although flood occurs frequently, the level of awareness and preparedness among communities in the state of Pahang were questionable. Thus, the primary goal of this study is to analyse the impact on quality of life of floodaffected communities in Temerloh, Pekan and Kuantan.

\section{METHODS}

Study area and study population

A cross-sectional study was conducted among 602 flood victims from 3 worst flood districts in Pahang namely Pekan, Kuantan and Temerloh. The study was conducted for five months from May to September, 2015. The selection of the respondents were conducted via stratified random sampling based on the data from respective district offices.

\section{Study Instrument}

The impact of the flooding on the quality of life (QOL) was assessed through the WHOQOL instruments. The WHOQOL-BREF is a self-report which consist of 26-items on QOL inventory developed by the World Health Organization. This self-report assess four major domains including physical, psychological, social relationship and environment. The local validation of the tool used in this study was evaluated to be compatible with a local setting. All the questions in the WHOQOLBREF report were scored in such a way that the higher scores indicates a better QOL. Subsequently, the total scores were divided into low and high QOL based on the overall means of these findings.

\section{Statistical Analysis}

All the data collected from the questionnaire were statistically analysed by using SPSS version 21 , to determine the percentage, frequency and crosstabulation (chi-square). Analysis of Multiple logistic 
regression was conducted to get an adjusted odds ratio (aOR) of the factors towards QOL.

\section{RESULTS}

Respondents Characteristics

Table 1 showed the characteristics of the respondents' in this study. The gender distributions showed that male population dominated with percentage of $63.8 \%(n=384)$ and females with percentage of $36.2 \%(n=218)$. The majority of the respondents' age were ranged between 19 to 88 years old with the highest respondents were belonging to the age group between 41-65 years old. A total of $55.3 \%$ of the respondents were classified as ruralites, and the remaining were urbanites. The grouping by ethnicity,shows that Malays predominated with $97.8 \%$ while other races were minority in this vicinity. Many of the respondents were married $(80.4 \%)$ and received primary and secondary education (84.2\%). Majority of the flood victims had an income below than MYR2000.

Table 1: Summary of demographic characteristics

\begin{tabular}{|c|c|c|}
\hline Variables $(n=602)$ & Frequency $(\mathrm{N})$ & Percent $(\%)$ \\
\hline \multicolumn{3}{|l|}{ Gender } \\
\hline Male & 384 & 63.8 \\
\hline Female & 218 & 36.2 \\
\hline \multicolumn{3}{|l|}{ Age (Years) } \\
\hline $0-18$ & 1 & 0.2 \\
\hline $19-40$ & 181 & 30.1 \\
\hline $41-65$ & 353 & 58.6 \\
\hline 66 and above & 67 & 11.1 \\
\hline \multicolumn{3}{|l|}{ Strata } \\
\hline Urban & 269 & 44.7 \\
\hline Rural & 333 & 55.3 \\
\hline \multicolumn{3}{|l|}{ Ethnicity } \\
\hline Malay & 589 & 97.8 \\
\hline Chinese & 4 & 0.7 \\
\hline Indian & 2 & 0.3 \\
\hline Orang Asli (Indigenous) & 2 & 0.3 \\
\hline Others & 5 & 0.8 \\
\hline \multicolumn{3}{|l|}{ Religion } \\
\hline Islam & 598 & 99.3 \\
\hline Hindu & 2 & 0.3 \\
\hline Buddha & 2 & 0.3 \\
\hline \multicolumn{3}{|l|}{ Marital Status } \\
\hline Single & 31 & 5.1 \\
\hline Married & 484 & 80.4 \\
\hline Divorced & 10 & 1.7 \\
\hline Widowed & 76 & 12.6 \\
\hline Others & 1 & 0.2 \\
\hline \multicolumn{3}{|l|}{ Level of Education } \\
\hline Never Schooled & 17 & 2.8 \\
\hline Primary School & 147 & 24.4 \\
\hline Primary School & 115 & 19.1 \\
\hline Secondary School & 245 & 40.7 \\
\hline Diploma & 36 & 6.0 \\
\hline Vocational & 3 & 0.5 \\
\hline Degree & 35 & 5.8 \\
\hline Others & 3 & 0.5 \\
\hline Not Answered & 1 & 0.2 \\
\hline \multicolumn{3}{|c|}{ Household Income (MYR/Month) } \\
\hline \multicolumn{3}{|l|}{ No Income } \\
\hline < MYR 1000 & 19 & 3.2 \\
\hline MYR $1001-2000$ & 240 & 39.9 \\
\hline MYR $2001-3000$ & 201 & 33.4 \\
\hline MYR $3001-4000$ & 67 & 11.1 \\
\hline \multirow[t]{2}{*}{ > MYR 4001} & 38 & 6.3 \\
\hline & 37 & 6.1 \\
\hline
\end{tabular}


Impact on Quality of Life

There were four domains seen on the quality of life (QOL) study of the flood victims. The percentage of the low QOL of these domains were as follows; i.e. low physical activity at $59.0 \%$, low psychological $(53.3 \%)$, low social relationships $(43.0 \%)$, and low environment (45.2\%) (Table 2).

Table 2: Quality of life by district in Pahang, Malaysia

\begin{tabular}{|c|c|c|c|c|c|c|}
\hline \multirow[b]{2}{*}{$\begin{array}{l}\text { Quality of Life } \\
(n=602)\end{array}$} & \multirow[b]{2}{*}{ PEKAN } & \multicolumn{2}{|l|}{ Mean (SD) } & \multirow[b]{2}{*}{$\begin{array}{l}\text { Overall } \\
\text { Mean }\end{array}$} & \multicolumn{2}{|c|}{$\mathrm{n}(\%)$} \\
\hline & & KUANTAN & TEMERLOH & & $\begin{array}{l}\text { Low } \\
\text { Quality of } \\
\text { Life } \\
(<\text { mean })\end{array}$ & $\begin{array}{l}\text { High } \\
\text { Quality of } \\
\text { Life } \\
\text { (>mean) }\end{array}$ \\
\hline \multirow{2}{*}{ Physical Activity } & 70.21 & 63.35 & 74.79 & 69.45 & 355 & 247 \\
\hline & $(14.70)$ & $(12.22)$ & $(13.23)$ & $(14.21)$ & $(59.0 \%)$ & $(41.0 \%)$ \\
\hline \multirow{2}{*}{ Phychological } & 72.63 & 64.62 & 76.78 & 71.36 & 321 & 281 \\
\hline & $(15.52)$ & $(13.15)$ & (13.09) & $(14.83)$ & $(53.3 \%)$ & $(46.7 \%)$ \\
\hline Social & 70.33 & 61.02 & 78.34 & 67.20 & 259 & 343 \\
\hline Relationship & (18.37) & $(15.78)$ & (16.68) & (18.52) & $(43.0 \%)$ & $(57.0 \%)$ \\
\hline \multirow{2}{*}{ Enviroment } & 67.05 & 62.66 & 74.22 & 68.00 & 272 & 330 \\
\hline & $(15.84)$ & $(13.16)$ & $(13.76)$ & $(15.05)$ & $(45.2 \%)$ & $(54.8 \%)$ \\
\hline
\end{tabular}

Counfounders were controlled via multiple logistic regression to determine the predictors contributing towards low QOL. The analysis (Table 3) showed that factors related to residing in the urban area, female gender, high education status and high household income level were associated with the reduced QOL of flood victims. In detail, low physical activity was associated with victims staying in the urban area, females, higher education level and high income. Besides, low psychology domain were associated with the victim's from urban and females. Meanwhile victim's living in an urban area was the only predictor for the low social relationship domain. Lastly, a low environment was associated with victim living in an urban area, females and higher education level.

Table 3: Significant factors associated with four domain of QOL

\begin{tabular}{|c|c|c|c|c|c|c|c|c|}
\hline \multirow[t]{2}{*}{ Variables } & & \multicolumn{3}{|c|}{ Quality of Life - Physical Activity } & \multicolumn{4}{|c|}{$95 \% \mathrm{CI}$} \\
\hline & & Low & High & $\chi^{2}$ value & p-value & $\mathrm{aOR} *$ & Lower & Upper \\
\hline \multirow{2}{*}{ Gender } & Male & $205(53.4)$ & 179 (46.6) & \multirow{2}{*}{13.669} & \multirow{2}{*}{$<0.001$} & \multirow{2}{*}{1.926} & \multirow{2}{*}{1.358} & \multirow{2}{*}{2.733} \\
\hline & Female & $150(68.8)$ & $68(31.2)$ & & & & & \\
\hline \multirow{2}{*}{ Strata } & Urban & $200(74.3)$ & $69(25.7)$ & \multirow{2}{*}{47.539} & \multirow{2}{*}{$<0.001$} & \multirow{2}{*}{0.300} & \multirow{2}{*}{0.212} & \multirow{2}{*}{0.426} \\
\hline & Rural & $155(46.5)$ & $178(53.5)$ & & & & & \\
\hline \multirow{2}{*}{ Education } & Low & $302(57.2)$ & $226(42.8)$ & \multirow[b]{2}{*}{5.581} & \multirow[b]{2}{*}{0.018} & \multirow[b]{2}{*}{1.889} & \multirow[b]{2}{*}{1.107} & \multirow[b]{2}{*}{3.222} \\
\hline & High & $53(71.6)$ & $21(28.4)$ & & & & & \\
\hline \multirow{2}{*}{ Income } & Low & $257(55.9)$ & $203(44.1)$ & \multirow{2}{*}{7.748} & \multirow{2}{*}{0.005} & \multirow{2}{*}{1.759} & \multirow{2}{*}{1.179} & \multirow{2}{*}{2.626} \\
\hline & High & $98(69.0)$ & $44(31.0)$ & & & & & \\
\hline \multicolumn{9}{|c|}{ Quality of Life - Psychology } \\
\hline \multirow{2}{*}{ Gender } & Male & $192(50.0)$ & $192(50.0)$ & \multirow{2}{*}{4.702} & \multirow{2}{*}{0.030} & \multirow{2}{*}{1.449} & \multirow{2}{*}{1.036} & \multirow{2}{*}{2.028} \\
\hline & Female & $129(59.2)$ & $89(40.8)$ & & & & & \\
\hline & Urban & $171(63.6)$ & $98(36.4)$ & & < & 0 & 0 & \\
\hline Strata & Rural & $150(45.0)$ & $183(55.0)$ & 20.513 & $<0.001$ & $0.4 / 0$ & 0.338 & 0.658 \\
\hline & & Quality of & ife - Social $\mathrm{F}$ & elationship & & & & \\
\hline & $0-18$ years & $0(0.0)$ & $1(100.0)$ & 28.133 & $<0.001$ & - & - & - \\
\hline & $19-40$ years & $99(54.7)$ & $82(45.3)$ & & & - & - & - \\
\hline Age & $41-65$ years & $121(34.4)$ & $232(65.7)$ & & & - & - & - \\
\hline & 66 and above & $39(58.2)$ & $28(41.8)$ & & & - & - & - \\
\hline & Urban & $139(51.7)$ & $130(48.3)$ & & & & & \\
\hline Strata & Rural & $120(36.0)$ & $213(64.0)$ & 14.842 & $<0.001$ & 0.527 & 0.380 & 0.731 \\
\hline
\end{tabular}




\begin{tabular}{|c|c|c|c|c|c|c|c|c|}
\hline \multirow{3}{*}{ Gender } & & Qualit & f Life - Env & & \multirow{3}{*}{0.003} & \multirow{3}{*}{1.662} & \multirow{3}{*}{1.189} & \multirow{3}{*}{2.324} \\
\hline & Male & $156(40.6)$ & $228(59.4)$ & \multirow{2}{*}{8.894} & & & & \\
\hline & Female & $116(53.2)$ & $102(46.8)$ & & & & & \\
\hline \multirow[b]{2}{*}{ Strata } & Urban & $148(55.0)$ & $121(45.0)$ & \multirow{2}{*}{18.995} & \multirow[b]{2}{*}{$<0.001$} & \multirow[b]{2}{*}{0.485} & \multirow[b]{2}{*}{0.350} & \multirow[b]{2}{*}{0.673} \\
\hline & Rural & $124(37.2)$ & $209(62.8)$ & & & & & \\
\hline \multirow{2}{*}{ Education } & Low & $230(43.6)$ & $298(6.4)$ & \multirow{2}{*}{4.563} & \multirow{2}{*}{0.033} & \multirow{2}{*}{1.701} & \multirow[b]{2}{*}{1.041} & \multirow[b]{2}{*}{2.779} \\
\hline & High & $42(56.8)$ & 32 (43.2) & & & & & \\
\hline
\end{tabular}

*aOR - adjusted odds ratio controlling gender, strata, education, income, age; CI confidence interval

\section{DISCUSSION}

Generally, flood events will reduce the quality of life and all the flood victims would experience this effect. The severity of the quality of life was the only range that differ between one victim to another victim. This study has found that the impact of QOL was more profound in the physical and psychological domain. This finding was in accordance with previous studies findings. ${ }^{14,22}$ Previous findings on QOL among the victims was not only restricted to the floods but also covers other disasters such as wildfire ${ }^{21}$ and earthquake, ${ }^{23}$ these tragedies had major impact too. The immediate implications of floods involve loss of family members, property damage, destruction of crops and loss of livestock which may contribute to the lower QOL score in the two domains. Besides, the bad experience from floods such as shock and high level of stress could also adds to these scenarios. ${ }^{24}$ The ascpects in mental health especially in relation to the emotional problems were the main issues and may be experienced by any victims of disaster including floods. ${ }^{25}$

The more significant impact of low QOL among flood victims in this study were among people living in the urban area, women and those with higher socioeconomic level. Urbanisation itself could increase the pluvial and fluvial flood risk $^{26}$ due to an unplanned development and urban migration. ${ }^{27}$ This leads to a disastrous flood to occur in the urban area and indirectly give more impact on QOL among the residents. Lower QOL is not the only effect of post-flood event, but also influenced by other disasters. ${ }^{17}$

Women were highly affected in terms of their QOL after a natural disaster such as flood. ${ }^{28}$ This could be due to the fact that women plays an essential role in providing for the family livelihood. However, their tasks and workload may increase after the disaster and this may affect their well-being status. ${ }^{29}$ A recent qualitative study has also found that two main themes were closely related to mental health among women post-disaster, including physical and external environment. The mental health problem does also include psychological factors. Both the theme or domain have significant effect towards the psychological factors among women as compared to the men.

Victims with low income suffer greater losses from floods than the households with high income.$^{30}$ However, this may be different in terms of their QOL status. The relationship between disaster losses and the level of economic development is nonlinear, suggesting that a country is more disaster resilience at a lower income level, but at a higher income level, a country become less disaster resistant. ${ }^{31}$ Thus, this supports the poorer QOL in a lower socioeconomic situation.

\section{CONCLUSION}

The quality of life of the community is vital to regain back the socio-economic strength for the community to strive. In addition, the need of endorsement of future preventive measures through risk assessment and impacts with solutions, are needed to uphold a better adaptive strategies. Such plan also includes ways to reduce hazards and risks of flood disaster within the potential areas of flood risk in the country. One of the important strategies that we recently found was through community empowerment (32). Through this study, we hope to clarify the details and issues regarding the health and well-being of the community for public concerns and future initiatives agendas.

\section{COMPLIANCE WITH ETHICAL STANDARDS}

This study was approved by the Department of Community Health and the Research and Ethics Committee of Universiti Kebangsaan Malaysia Medical Centre (UKMMC). All respondents were given pertinent information and informed consent to participate. There were no competing interests to be declared.

\section{ACKNOWLEDGMENT}

We gratefully acknowledge funding support from the Ministry of Education Malaysia, under Floods Management Grant, the year 2015 under TransDisciplinary Research Grant Scheme, TRGS (TRGS/1/2015/UKM/01/1). We would also like to thank the district and land officer of Temerloh, Pekan and Kuantan for their full cooperation and commitment in this research. Last but not least, we would like to convey our utmost appreciation to the respondents who had participated in our study.

\section{FUNDING}


This study was funded by the Ministry of Education Malaysia, under Floods Management Grant 2015 under Trans-Disciplinary Research Grant Scheme, TRGS (TRGS/1/2015/UKM/01/1).

\section{REFERENCES}

1. Alderman K, Turner LR \& Tong S. Floods and human health: a systematic review. Environment international. 2012; 47: 3747.

2. Hettiarachchi S, Wasko C \& Sharma A. Increase in flood risk resulting from climate change in a developed urban watershed-the role of storm temporal patterns. 2018.

3. Arnell NW \& Gosling SN. The impacts of climate change on river flood risk at the global scale. Climatic Change. 2016; 134 (3): 387-401.

4. Gasim MB, Toriman ME \& Abdullahi MG. Floods in Malaysia historical reviews, causes, effects and mitigations approach. International Journal of Interdisciplinary Research and Innovations. 2014; 2(4): 5965.

5. Sulaiman WNA, Heshmatpoor A \& Rosli MH. Identification of Flood Source Areas in Pahang River Basin, Peninsular Malaysia. Environment Asia. 2010; 3:73-8.

6. Chia C. Managing flood problems in Malaysia. Bulletin Ingenieur. 2004; 22(68):38-43.

7. Ghani AA, Chang CK, Leow CS \& Zakaria NA. Sungai Pahang digital flood mapping: 2007 flood. International journal of river basin management. 2012; 10(2):139-48.

8. Shafie A. A Case study on floods of 2006 and 2007 in Johor, Malaysia. Colorado State University. 2009.

9. Radi MFM, Hashim JH, Jaafar MH, Hod R, Ahmad N, Nawi AM Baloch et al. Leptospirosis outbreak after the 2014 major flooding event in Kelantan, Malaysia: a spatial-temporal analysis. The American journal of tropical medicine and hygiene. 2018; 98(5): 1281-95.

10. Puteh SEW, Siwar C, Hod R, Nawi AM, Idris IB, Ahmad IS, et al. Burden of Healthrelated Issues and Community Empowerment in Malaysia's East Coast Flood. Improving Flood Management, Prediction and Monitoring: Case Studies in Asia. Emerald Publishing Limited. 2018.

11. Du W, Fitzgerald GJ, Clark M \& Hou XY. Health impacts of floods. Prehosp Disaster Med. 2010; 25(3): 265-72.

12. Idris IB, Puteh SEW, Hod R, Nawi AM, Ahmad IS, Siwar C \& Taha MR. Mental health disorder among post flood victims in
Pahang. Asean Journal of Psychiatry. 2018; 19 (2).

13. Fullerton CS \& Ursano RJ. Posttraumatic stress disorder: Acute and long-term responses to trauma and disaster. 1997.

14. Tan H, Luo Y, Wen S, Liu A, Li S, Yang T. \& Sun Z. The effect of a disastrous flood on the quality of life in Dongting lake area in China. Asia Pacific Journal of Public Health. 2004; 16(2):126-32.

15. Chang CH, Cella D, Masters GA, Laliberte N, O'brien P, Peterman A \& Shevrin D. Real-time clinical application of qualityof-life assessment in advanced lung cancer. Clinical lung cancer. 2002; 4 (2):104-09.

16. World Health Organization. WHOQOL: Measuring Quality of Life. Programme on mental health. Geneva, Switzerland: World Health Organization; 1997.

17. Ardalan A, Mazaheri M, Vanrooyen M, Mowafi H, Nedjat S, Naieni KH \& Russel M. Post-disaster quality of life among older survivors five years after the Bam earthquake: implications for recovery policy. Ageing \& Society. 2011; 31(2):179-96.

18. Ceyhan E \& Ceyhan AA. Earthquake survivors' quality of life and academic achievement six years after the earthquakes in Marmara, Turkey. Disasters. 2007; 31(4):516-29.

19. Ke X, Liu C \& Li N. Social support and Quality of Life: a cross-sectional study on survivors eight months after the 2008 Wenchuan earthquake. BMC Public Health. 2010; 10(1): 573.

20. Waelveerakup W. The quality of life of flood survivors in Thailand, Nakhon Pathom Rajabhat University. Australasian Emergency Nursing Journal. 2014; 17(1):19-22.

21. Papanikolaou V, Adamis D \& Kyriopoulos J. Long term quality of life after a wildfire disaster in a rural part of Greece. Open Journal of Psychiatry.2012; 2(2):64.

22. Ahmad Z, Hassan NFN, Hamid AC, Rahman BA, Baharuddin NS \& Mohamad Z. Assessing the Effects of Physical and Mental Health on Quality of Life at Flood Transfer Center. International Journal of Business and Management. 2018; 2(1): 7882.

23. Valenti M, Masedu F, Mazza M, Tiberti S, Di Giovanni C, Calvarese A, et al. A longitudinal study of quality of life of earthquake survivors in L'Aquila, Italy. BMC public health, 2013; 13(1):1143.

24. Nasir R, Zainah A \& Khairudin R. Psychological effects on victims of the 
Johor flood 2006/2007. Asian Social Science.2012; 8(8):126-33.

25. Stanke C, Murray V, Amlôt R, Nurse J \& Williams R. The effects of flooding on mental health: Outcomes and recommendations from a review of the literature. PLoS currents. 2012; 4.

26. Miller JD \& Hutchins M. The impacts of urbanisation and climate change on urban flooding and urban water quality: A review of the evidence concerning the United Kingdom. Journal of Hydrology: Regional Studies. 2017; 12:345-62.

27. United Nations Environment Programme. UNEP Frontiers 2016 Report: Emerging issues of environmental concern. United Nations Environment Programme Nairobi. 2016.

28. Wu J, Xiao J, Li T, Li X, Sun H, Chow EP, Lu Y, Tian T, Li X \& Wang Q. A crosssectional survey on the health status and the health-related quality of life of the elderly after flood disaster in Bazhong city, Sichuan, China. BMC public health. 2015; 15(1):163.

29. Sohrabizadeh S, Jahangiri K, Jazani RK, Babaie J, Moradian MJ \& Rastegarfar B. Women's challenges and capabilities in disasters: A case report of the twin earthquakes of Eastern Azerbaijan, Iran. PLoS currents. 2017; 9.

30. De Silva M \& Kawasaki A. Socioeconomic vulnerability to disaster risk: a case study of flood and drought impact in a rural Sri Lankan community. Ecological Economics. 2018; 152: 131-40.

31. Padli J \& Habibullah MS. Natural disaster death and socio-economic factors in selected Asian countries: A panel data analysis. 2008.

32. Hod R, Sivasamy H, Puteh SEW, Nawi AM, Idris IB, Ahmad IS et al. Community Empowerment and the Associated Factors among the 2014 Flood Victims in Pahang. Universal Journal of Public Health. 2017; 5(3): 119-26. 